\title{
Quality of care in long-term care institutions: A scoping review of literature
}

\author{
Qualidade do cuidado em instituições de longa permnência: Uma revisão de escopo da literatura \\ Calidad de la atención en las instituciones de atención a largo plazo: Una revisión de alcance de la
}

literatura

Received: 06/12/2021 | Reviewed: 06/22/2021 | Accept: 06/24/2021 | Published: 07/10/2021

\author{
Bruno Luís de Carvalho Vieira \\ ORCID: https://orcid.org/0000-0002-1457-7754 \\ Universidade Federal de Minas Gerais, Brazil \\ E-mail: obrunocarvalho@ hotmail.com \\ Arianne Correa Martins \\ ORCID: https://orcid.org/0000-0003-3975-7142 \\ Universidade Federal de Minas Gerais, Brazil \\ E-mail: arianne20@outlook.com \\ Raquel Conceição Ferreira \\ ORCID: https://orcid.org/0000-0001-8897-9345 \\ Universidade Federal de Minas Gerais, Brazil \\ E-mail: raquelconceicaoferreira@gmail.co \\ Andréa Maria Duarte Vargas \\ ORCID: https://orcid.org/0000-0002-4371-9862 \\ Universidade Federal de Minas Gerais, Brazl \\ E-mail: vargasnt@task.com.br
}

\begin{abstract}
This review sought to answer the question "What theoretical models have been used to define and evaluate the quality of care provided to older adults in long-term care institutions?" The employed study methodology followed the recommendations of the Joanna Briggs Institute Reviewers Manual. Using MESH terms and keywords such as "elderly," "long-term care," and "theoretical," four electronic databases (i.e., PubMed, Scopus, Web of Science, and LILACS) were searched for articles in Portuguese, English, and Spanish, without a time frame restriction. Titles and abstracts were independently screened by two reviewers, followed by a full-text review. A total of 1,211 articles met our inclusion criteria, 80 were selected for full reading, and 21 were included for qualitative synthesis. The theoretical models cited in the studies included the multidimensional model $(\mathrm{n}=10)$; the structure, process, and results model ( $\mathrm{n}$ $=8)$; a theory centered on the person $(n=2)$; and one centered on the work environment $(n=1)$. Few articles used a conceptual model as the basis for assessing long-term care institutions, which is important for the construction of instruments and indicators that assess the quality of care.
\end{abstract}

Keywords: Quality of care; Theoretical model; Long-term care for the aged; Elder.

\section{Resumo}

Esta revisão buscou responder à questão "Quais modelos teóricos têm sido utilizados para definir e avaliar a qualidade da assistência prestada a idosos em instituições de longa permanência?” A metodologia de estudo empregada seguiu as recomendações do Joanna Briggs Institute Reviewers Manual. Usando termos MESH e palavras-chave, como "idosos," "instituição de longa permanência para idosos" e "teoria", quatro bases de dados eletrônicos (PubMed, Scopus, Web of Science e LILACS) foram pesquisadas e incluídos artigos em português, inglês e espanhol, sem restrição de data. Os títulos e resumos foram selecionados de forma independente por dois revisores, seguidos de uma revisão do texto completo. Um total de 1.211 artigos preencheram nossos critérios de inclusão, 80 foram selecionados para leitura na íntegra e 21 foram incluídos para uma síntese qualitativa. Os modelos teóricos citados nos estudos incluíram o modelo multidimensional $(n=10)$; a estrutura, processo, resultados $(n=8)$; uma teoria centrada na pessoa $(\mathrm{n}=2)$; e uma centrada no ambiente de trabalho $(\mathrm{n}=1)$. Poucos artigos utilizaram um modelo conceitual como base para a avaliação das instituições de longa permanência, o que é importante para a construção de instrumentos e indicadores que avaliem a qualidade do cuidado.

Palavras-chave: Qualidade do cuidado; Modelo teórico; Instituições de longa permanência para idosos; Idosos.

\section{Resumen}

Esta revisión busca dar respuesta a la pregunta "¿Qué modelos teóricos se han utilizado para definir y evaluar la calidad de la atención brindada a los individuos en instituciones de largo plazo?" La metodología de estudio realizada fue seguida como recomendaciones por el Manual de Revisores del Instituto Joanna Briggs. Utilizando términos MESH y palabras chave, como "idosos", "instituição de longa permanência para idosos" y "teoría", se buscaron cuatro 
bases de datos electrónicos (PubMed, Scopus, Web of Science y LILACS), incluidos artículos en portugués, inglés y español, con restricción de datos. Dos revisores seleccionaron de forma independiente los títulos y los resúmenes, seguidos de una revisión del texto completo. Un total de 1211 artículos cumplimentaron previamente nuestros criterios de inclusión, 80 seleccionados para su lectura completa y 21 incluidos para una revisión cualitativa. Los modelos teóricos citados en nuestros estudios incluyeron el modelo multidimensional ( $\mathrm{n}=10$ ); una estructura, proceso, resultados $(n=8)$; una teoría centrada en el peso $(n=2)$; un entorno no laboral centrado $(n=1)$. Poucos artigos utilizará un modelo conceptual como base para la evaluación de instituciones de largo plazo, o que sea importante para la construcción de instrumentos e indicadores que evalúen la calidad de la asistencia.

Palabras clave: Calidad de la atención; Modelo teórico; Instituciones de larga estancia para ancianos; Personas mayores

\section{Introdution}

Population aging is a worldwide phenomenon that occurs in conjunction with an increasing number of older adults with functional impairment and dependence on daily activities. These older adults need continuous and long-term care that is not always offered by their families. In this context, institutionalization has become an alternative for families (Joshua 2017; Burke \& Werner 2019).

Globally, there are different types of long-term care institutions (LTCIs) for older adults, with different denominations but common characteristics. These institutions are collective residences for older adults, with or without the need for assistance in activities of daily living (ADLs) or with behavioral problems. The function of LTCIs is to supply homes where the resident can have protection, citizenship, freedom, family support, and the chance to preserve functional status (Onder et al. 2012; Sanford et al. 2015; WHO 2017; Trinkoff et al. 2020).

To verify the quality of care offered by LTCIs, many types of assessments have been developed and applied to guide the choices of residents or the investments by local governments (Spasova et al. 2018; Scheffelaar et al. 2019 ; Milte et al. 2019; Wagner et al. 2020; Sion et al. 2020), and the use of multiple dimensions and indicators for assessment is recommended (Gilissen et al. 2017; Dyer et al. 2019).

To construct evaluation instruments, it is vital to have a theory to direct the research, guide what will be evaluated, and guide how something will be measured. The choice of the theoretical framework to achieve this requires in-depth knowledge of the topic being studied (Adom et al. 2018; Collins et al. 2018; Varpio et al. 2019). According to the World Health Organization (WHO), a definition of quality must be effective, efficient, accessible, patient-centered, fair, and safe (WHO 2006). The mapping of theoretical models used by researchers to assess the quality of care in LTCIs systematizes the theory employed and contributes to the comparison of them and the choice of the theoretical framework for the design of future studies. Therefore, the objective of this study was to map the theoretical frameworks used to define and assess the quality of care in LTCIs.

\section{Methodology}

The present study is a scoping review conducted according to the methodological guidelines of the Joanna Briggs Institute Reviewers Manual (Peters et al. 2015). This type of research map key concepts, summarize theories and clarify the conceptual limits and gaps in the scientific literature (Levac et al. 2010; Tricco et al. 2016; Munn et al. 2018). The Preferred Reporting Items for Systematic reviews and Meta-Analyses extension for Scoping Reviews (PRISMA-ScR) checklist was employed in this review.

The following methodological steps were followed: (1) identification of the research problem, (2) development of the eligibility criteria, (3) definition of the search strategy, and (4) qualitative synthesis of the results (Armstrong et al. 2011; Peters et al. 2015). 


\subsection{Research problem identification}

This research was conducted due to the need to identify theoretical models to evaluate the quality of care in the context of LTCIs. The PCC framework (population, concept, and context) structured the construction of the research question. Meanwhile, the population included institutionalized older adults, the concept refers to the theoretical models used to guide the assessment of the quality of care, and the context was the LTCIs themselves (Peters et al. 2015). Therefore, the research question was defined as follows: What theoretical models have been used to define and assess the quality of care for older adults in LTCIs?

\subsection{Development of eligibility criteria}

The eligibility criteria for inclusion in our analysis were (1) studies in English, Portuguese, and Spanish; (2) original studies with a quantitative or qualitative approach; (3) studies that presented a theoretical model for assessing the quality of care in an LTCI, and (4) studies conducted in an LTCI. There was no time limit restriction for studies. Editorials, book chapters, dissertations, and conference abstracts were excluded.

\subsection{Search strategy}

The search was carried out between July 2020 and February 2021 in the following electronic databases: Web of Science, PubMed, LILACS, and Scopus. The search strategy included descriptors indexed in the Medical Subject Headings (MESH) joined by Boolean AND and OR. The descriptors were separated into four blocks (quality of care, LTCI, older adults, and theoretical model) and the search strategy was adapted according to each electronic database (Table 1). A manual search was also carried out by consulting the list of references of the included articles.

Table 1. Search strategy on the electronic databases

\begin{tabular}{|c|c|}
\hline Database & Keywords \\
\hline $\begin{array}{l}\text { Web of } \\
\text { Science }\end{array}$ & $\begin{array}{l}\text { ("quality of care"[All Fields] OR "quality of healthcare"[All Fields] OR "quality of health care"[All Fields] OR "quality } \\
\text { indicator*"[All Fields] OR "quality measure*"[All Fields] OR "quality assess*"[All Fields] OR "quality evaluation"[All } \\
\text { Fields]) AND ("nursing home"[All Fields] OR "nursing homes"[All Fields] OR "homes for the aged"[All Fields] OR } \\
\text { "residential care home"[All Fields] OR "long term facilit*"[All Fields] OR "homes nursing"[All Fields] OR "residential } \\
\text { care"[All Fields] OR "residential care institutions"[All Fields] OR "long-term care"[All Fields] OR "long-term care"[All } \\
\text { Fields] OR "care home"[All Fields]) AND ("elder"[All Fields] OR "elder*"[All Fields] OR ("aged"[MeSH Terms] OR } \\
\text { "aged"[All Fields]) OR "geriatric*"[All Fields] OR "gerontol*"[All Fields] OR "older adult*"[All Fields] OR "aging"[All } \\
\text { Fields]) AND ("theoretical model"[All Fields] OR "theoretical framework"[All Fields] OR "theory"[All Fields] OR } \\
\text { "measure*"[All Fields] OR "models theoretical"[All Fields] OR "theoretical study"[All Fields] OR "conceptual model"[All } \\
\text { Fields] OR "conceptual framework"[All Fields]) }\end{array}$ \\
\hline PubMed & $\begin{array}{l}\text { ("quality of care"[All Fields] OR "quality of healthcare"[All Fields] OR "quality of health care"[All Fields] OR "quality } \\
\text { indicator*"[All Fields] OR "quality measure*"[All Fields] OR "quality assess*"[All Fields] OR "quality evaluation"[All } \\
\text { Fields]) AND ("nursing home"[All Fields] OR "nursing homes"[All Fields] OR "homes for the aged"[All Fields] OR } \\
\text { "residential care home"[All Fields] OR "long term facilit*"[All Fields] OR "homes nursing"[All Fields] OR "residential } \\
\text { care"[All Fields] OR "residential care institutions"[All Fields] OR "long-term care"[All Fields] OR "long-term care"[All } \\
\text { Fields] OR "care home"[All Fields]) AND ("elder"[All Fields] OR "elder*"[All Fields] OR ("aged"[MeSH Terms] OR } \\
\text { "aged"[All Fields]) OR "geriatric*"[All Fields] OR "gerontol*"[All Fields] OR "older adult*"[All Fields] OR "aging"[All } \\
\text { Fields]) AND ("theoretical model"[All Fields] OR "theoretical framework"[All Fields] OR "theory"[All Fields] OR } \\
\text { "measure*"[All Fields] OR "models theoretical"[All Fields] OR "theoretical study"[All Fields] OR "conceptual model"[All } \\
\text { Fields] OR "conceptual framework"[All Fields]) }\end{array}$ \\
\hline Scopus & $\begin{array}{l}\text { ( ( "quality of care" OR "quality of healthcare" OR "quality of health care" OR "quality indicator" OR "quality } \\
\text { measure*" OR "quality assess*" OR "quality evaluation" ) ) AND ( ( ( ( "Nursing Homes" [mesh] OR "Homes for the } \\
\text { Aged" [mesh] OR residential AND care AND home*[title/abstract] OR "long AND term AND facilit*" OR "homes, } \\
\text { AND nursing" OR "residential AND care" OR "residential AND care AND institutions" OR "long-term AND care" } \\
\text { OR "long AND term AND care" OR "care AND home*" )) ) AND ( ( elder* OR aged OR geriatric* OR "older }\end{array}$ \\
\hline
\end{tabular}


AND adults" OR "aging") ) ) AND ( ( "theoretical model" ) OR ( "theoretical framework" ) OR ( "theory" ) OR ( "measure" ) OR ( "models theoretical" ) OR ( "theoretical study" ) OR ( "conceptual model" ) AND ( "conceptual framework" ) )

LILACS $\quad$ ( ( "quality of care" OR "quality of healthcare" OR "quality of health care" OR "quality indicator" OR quality measure* OR "quality assess*" OR "quality evaluation") ) AND ( ( ( ("Nursing Homes" OR "Homes for the Aged" OR residential AND care AND home* OR long AND term AND facilit* OR "homes, AND nursing" OR "residential AND care" OR "residential AND care AND institutions" OR "long-term AND care" OR "long AND term AND care" OR "care AND home*")) ) AND ( ( elder* OR aged OR geriatric* OR “older AND adults" OR "aging")) ) AND ( ( "theoretical model" ) OR ( "theoretical framework" ) OR ( "theory" ) OR ( "measure" ) OR ( "models theoretical" ) OR ( "theoretical study" ) OR ( "conceptual model" ) AND ( "conceptual framework" ) )

Source: Authors.

\subsection{Qualitative summary of results}

Relevant studies were initially identified. The software Microsoft Excel@ was used to identify and exclude duplicate articles. Two independent researchers (BLCV and ACM) selected the studies. The titles and abstracts were read for an initial screening, and the selected articles were read in full by both researchers. Disagreements about inclusions were discussed between the two researchers until a consensus was reached; if consensus could not be reached, disagreements were discussed with another researcher. According to the guidelines of a scoping review, an assessment of the quality of the selected articles was not carried out.

Information was then extracted from the selected studies using a table in Microsoft Excel® with the following information: author, year of publication, the country where the research was conducted, objectives, sample composition, variables used, data collection method, and dimensions of quality of care used to assess the quality of care in LTCIs. Theories were identified as multidimensional, when indicated in articles with that denomination or when citing the dimensions used to assess quality; structure-process-result, when the author used that term or indicated the study to follow Donabedian theory; person-centered, when it was described as based on consumer preference or satisfaction; and worker-centered, when the evaluation involved the worker's action on residents' well-being.

\section{Results}

A total of 1,216 studies were retained; 7 were duplicated. Of the studies, 1,204 were screened by reading the titles and abstracts, and 80 were screened by reading the full texts. Five more studies were selected from the references of the articles selected for a complete reading (Figure 1). 
Figure 1. Search and exclusion flow diagram.

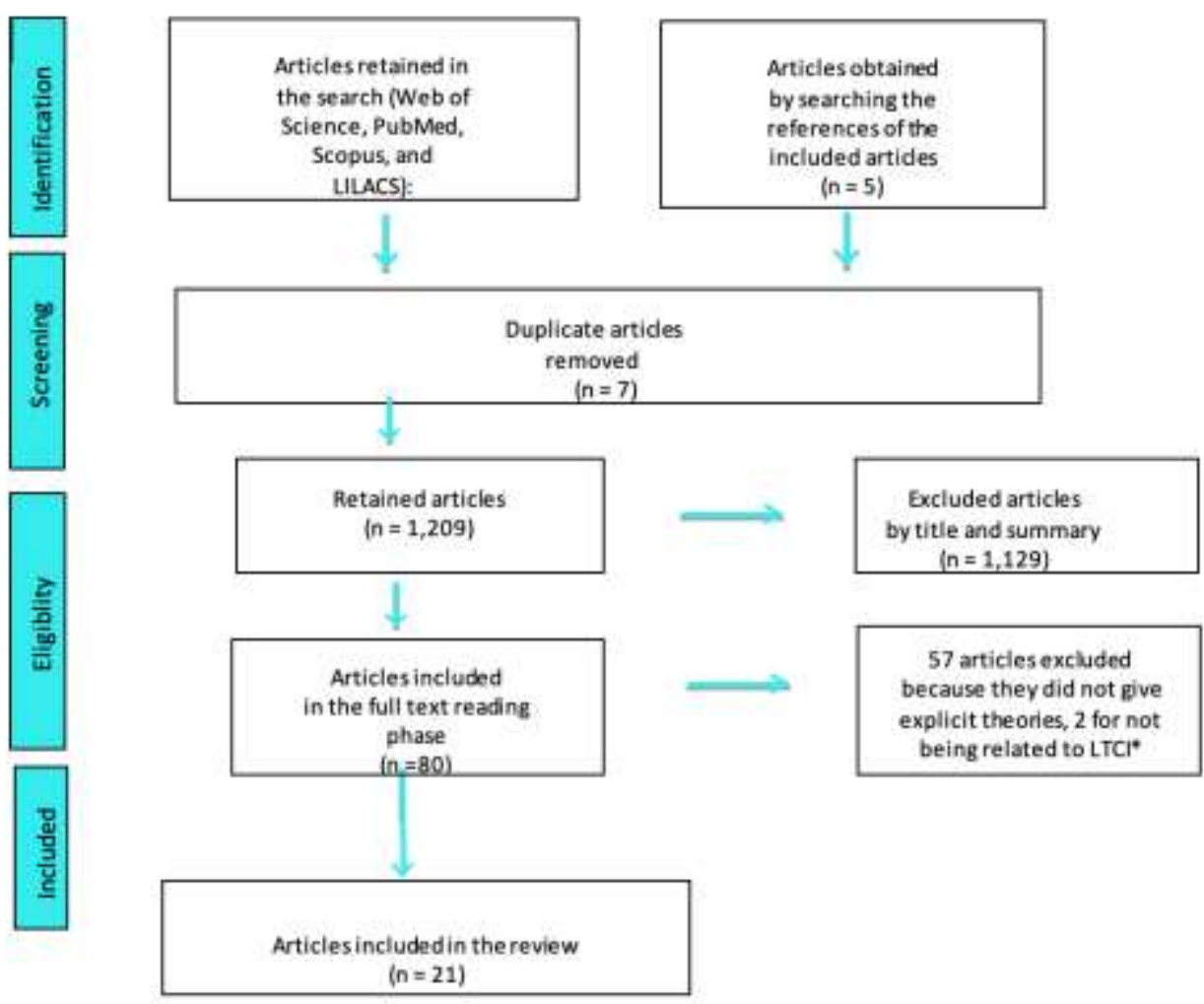

*LTCI - Long-term care institutions. Source: Joanna Briggs Institute Reviewers Manual (Peters et al. 2015) modified by the authors.

The search sequence, including and excluding criteria, was described in the flow chart (Figure 1). The selected articles were separated according to the theories used. Table 2 shows the information about the author(s), research site, type of study, objectives, sample composition and variables. After screening and applying the elegibility criteria, 21 articles were included in the review, most of which were cross-sectional $(n=13)$ and qualitative $(n=6)$; only two were longitudinal. Most studies were conducted in a single country, most often in the United States $(\mathrm{n}=10)$, the United Kingdom, Denmark, Finland, Israel, Lebanon, and Switzerland. There were five multicenter studies: one involving the Czech Republic, Finland, France, Germany, Italy, Israel, the Netherlands, and the United Kingdom; another involving Denmark, Iceland, Italy, and the United States; another involving the United States and Finland; another involving the United States, Canada, and Iceland; and another involving the United States and Iceland (Table 2).

The samples employed in the selected articles were LTCIs (Gustafson et al. 1990; Phillips et al. 1997; Saintfort et al. 1995; Rantz et al. 2000; Grabowski 2001; Rantz et al. 2002; Fleishman 1998; Weech-Maldonado et al. 2004; Laberge et al. 2008; Goodson et al. 2008; Thomas et al. 2012), residents and family members (Rantz et al. 1999), family members only (Thompson et al. 2012), residents only (Frijters et al. 2013; Malley et al. 2019; Kang et al. 2011; Kajonius \& Kazemi 2016; Abbott et al. 2018), LTCI`s administrators (Nasser; Doumit et al. 2011; Lowe et al. 2003) and LTCI`s workers (Winsløw; Borg, 2008).

The theoretical models used were structure-process-results, multidimensional, person-centered, and work-centered. 
Research, Society and Development, v. 10, n. 8, e17110817117, 2021

(CC BY 4.0) | ISSN 2525-3409 | DOI: http://dx.doi.org/10.33448/rsd-v10i8.17117

Table 2 Characteristics of included studies' author(s), place of research, type of study, objectives, sample composition, and variables, separated by theoretical model

\begin{tabular}{|c|c|c|c|c|c|c|c|}
\hline Author(s) & $\begin{array}{l}\text { Research } \\
\text { location }\end{array}$ & $\begin{array}{l}\text { Type of } \\
\text { study }\end{array}$ & $\operatorname{Aim}(s)$ & Population/sample & $\begin{array}{l}\text { Variable(s) / quality } \\
\text { indicator(s) used }\end{array}$ & Dimensions & Data collection method \\
\hline \multicolumn{8}{|c|}{ Multidimensional model } \\
\hline $\begin{array}{l}\text { Gustafson et al. } \\
1990\end{array}$ & United States & Qualitative & $\begin{array}{l}\text { To develop an instrument } \\
\text { for assessing } \\
\text { quality } \\
\text { in LTCIs }\end{array}$ & $\begin{array}{l}75 \text { LTCIs in Wisconsin, } 18 \text { in New } \\
\text { York, and } 18 \text { in Massachusetts }\end{array}$ & $\begin{array}{l}\text { Direct resident care, care process, } \\
\text { recreational activities, diet, and } \\
\text { relationship with family or community }\end{array}$ & $\begin{array}{l}\text { Did not relate } \\
\text { the dimensions } \\
\text { of quality }\end{array}$ & $\begin{array}{l}\text { Empirical model } \\
\text { validation using } \\
\text { multiattribute utility } \\
\text { (MAU), } \\
\text { with the creation and } \\
\text { use of the Quality } \\
\text { Assessment Index } \\
\text { (QAI) as a summary } \\
\text { measure of quality, } \\
\text { with comparability of } \\
\text { scores between LTCIs }\end{array}$ \\
\hline Phillips et al. 1997 & $\begin{array}{l}\text { Denmark, Iceland, } \\
\text { Italy, and the } \\
\text { United States }\end{array}$ & Cross-sectional & $\begin{array}{l}\text { To evaluate and compare } \\
\text { quality using secondary data } \\
\text { obtained using the Resident } \\
\text { Assessment Instrument } \\
\text { (RAI) }\end{array}$ & $\begin{array}{l}\text { All LTCIs in the United States, } 65 \\
\text { from Denmark, } 11 \text { from Iceland, and } \\
16 \text { from Italy }\end{array}$ & $\begin{array}{l}\text { Muscle contracture, pressure ulcers, } \\
\text { untreated depression, physical restraint, } \\
\text { use of psychotropic drugs, little or no } \\
\text { physical activity, falls, and weight loss }\end{array}$ & $\begin{array}{l}\text { Did not list the } \\
\text { dimensions }\end{array}$ & Secondary RAI data \\
\hline Saintfort et al. 1995 & $\begin{array}{l}\text { United States and } \\
\text { Finland }\end{array}$ & Cross-sectional & $\begin{array}{l}\text { To assess the relationship } \\
\text { between the concept and } \\
\text { quality measures with } \\
\text { organizational characteristics }\end{array}$ & 104 LTCIs & $\begin{array}{l}\text { Resident care, recreational activities, } \\
\text { facilities, and diet }\end{array}$ & $\begin{array}{l}\text { Variety and adequacy of } \\
\text { medical services, and } \\
\text { characteristics of the } \\
\text { facilities; quality of care } \\
\text { planning }\end{array}$ & $\begin{array}{l}\text { Application of the QAI } \\
\text { instrument and } \\
\text { collection of } \\
\text { organizational } \\
\text { characteristics }\end{array}$ \\
\hline Rantz et al. 1999 & United States & Qualitative & $\begin{array}{l}\text { To discover the dimensions } \\
\text { that define the quality } \\
\text { of care from the point of } \\
\text { view of home care } \\
\text { consumers }\end{array}$ & $\begin{array}{l}16 \text { LTCI residents and } \\
80 \text { family members }\end{array}$ & Teamwork and care & $\begin{array}{l}\text { Team, care, family } \\
\text { involvement, } \\
\text { communication, } \\
\text { environment, home, and } \\
\text { cost }\end{array}$ & Focus group \\
\hline
\end{tabular}


Research, Society and Development, v. 10, n. 8, e17110817117, 2021

(CC BY 4.0) | ISSN 2525-3409 | DOI: http://dx.doi.org/10.33448/rsd-v10i8.17117

\begin{tabular}{|c|c|c|c|c|c|c|c|}
\hline Rantz et al. 2000 & $\begin{array}{l}\text { United States and } \\
\text { Iceland }\end{array}$ & Qualitative & $\begin{array}{l}\text { To validate the Observable } \\
\text { Indicators instrument } \\
\text { of Nursing Home Care } \\
\text { Quality (QIC) }\end{array}$ & $\begin{array}{l}109 \text { LTCIs in the United States and } \\
11 \text { LTCIs in Iceland }\end{array}$ & $\begin{array}{l}\text { Interaction, individual care, workers, } \\
\text { environment, security, and social } \\
\text { environment }\end{array}$ & $\begin{array}{l}\text { Interaction, individual } \\
\text { care, LTCI`s workers, } \\
\text { environment, security, } \\
\text { and social environment }\end{array}$ & $\begin{array}{l}\text { Exploratory study and } \\
\text { focus groups }\end{array}$ \\
\hline Grabowski 2001 & United States & Longitudinal & $\begin{array}{l}\text { To assess how the } \\
\text { reimbursement of } \\
\text { Medicaid influences quality }\end{array}$ & $\begin{array}{l}15,067 \text { LTCIs participating in the } \\
\text { On-Line Survey, Certification, and } \\
\text { Reporting (OSCAR) system }\end{array}$ & $\begin{array}{l}\text { Registered nurses and number of nurses } \\
\text { per } 100 \text { residents, medication errors, } \\
\text { urethral catheters, feeding tube, physical } \\
\text { restraint, and number of disabilities } \\
\text { according to the Medicaid certification } \\
\text { process }\end{array}$ & $\begin{array}{l}\text { Did not list the } \\
\text { dimensions }\end{array}$ & $\begin{array}{l}\text { OSCAR data, Bureau } \\
\text { of Health Professions' } \\
\text { Area Resource File, the } \\
\text { State Data Book on } \\
\text { Long-Term Care } \\
\text { Program and Market } \\
\text { Characteristics, and } \\
1996 \text { data from HCFA } \\
\text { (Health Care Financing } \\
\text { Administration) area } \\
\text { wage indexes }\end{array}$ \\
\hline Rantz et al. 2002 & $\begin{array}{l}\text { Canada, } \\
\text { Iceland } \\
\text { United States }\end{array}$ & Qualitative & $\begin{array}{l}\text { To translate and validate the } \\
\text { questionnaire } \\
\text { (QIC) }\end{array}$ & $\begin{array}{l}12 \text { LTCIs in Iceland, } \\
1 \text { LTCI in Canada, and } \\
20 \text { LTCIs in the United States }\end{array}$ & $\begin{array}{l}\text { Care, communication, workers, and } \\
\text { environment family involvement, home, } \\
\text { and care }\end{array}$ & $\begin{array}{l}\text { Assistance and } \\
\text { communication work } \\
\text { team, environment, } \\
\text { family involvement, } \\
\text { house, and central focus } \\
\text { on care }\end{array}$ & $\begin{array}{l}\text { Consultation with } \\
\text { evaluators for } \\
\text { validation and } \\
\text { application in LTCIs }\end{array}$ \\
\hline $\begin{array}{l}\text { Thompson et al. } \\
2012\end{array}$ & Finland & Cross-sectional & $\begin{array}{l}\text { To report advanced } \\
\text { end-of-life quality concepts } \\
\text { in LTCIs }\end{array}$ & $\begin{array}{l}1,282 \text { family members of terminally } \\
\text { ill residents of } 85 \text { LTCIs }\end{array}$ & $\begin{array}{l}\text { Proportion of residents with advance } \\
\text { directives (living wills, orders not to } \\
\text { resuscitate, those not to be hospitalized, } \\
\text { and those without dietary restrictions), in } \\
\text { hospice, hospitalized or } \\
\text { sent to an emergency room, and in } \\
\text { feeding tubes }\end{array}$ & $\begin{array}{l}\text { The LTCI itself, } \\
\text { administrative } \\
\text { leadership, culture, and } \\
\text { care practices }\end{array}$ & $\begin{array}{l}\text { The LTCI itself. } \\
\text { Interview with family } \\
\text { members of residents } \\
\text { who died and lived } \\
\text { permanently and for at } \\
\text { least } 14 \text { days at LTCIs } \\
\text { and whose relatives } \\
\text { participated in the care } \\
\text { of these residents }\end{array}$ \\
\hline
\end{tabular}


Research, Society and Development, v. 10, n. 8, e17110817117, 2021

(CC BY 4.0) | ISSN 2525-3409 | DOI: http://dx.doi.org/10.33448/rsd-v10i8.17117

\begin{tabular}{|c|c|c|c|c|c|c|c|}
\hline Frijters et al. 2013 & $\begin{array}{l}\text { Czech Republic, } \\
\text { Finland, France, } \\
\text { Germany, Italy, } \\
\text { Israel, the } \\
\text { Netherlands, and } \\
\text { the United } \\
\text { Kingdom }\end{array}$ & Longitudinal & $\begin{array}{l}\text { To explain and discuss } \\
\text { quality indicators } \\
\text { related to the interRAI Long } \\
\text { Term Care Facility } \\
\text { instrument (interRAI-LTCI) }\end{array}$ & $\begin{array}{l}\text { 3,761 LTCI residents during initial } \\
\text { data collection and 2,686 during the } \\
\text { second collection }\end{array}$ & $\begin{array}{l}\text { Behavior problems, depression, } \\
\text { incontinence, urinary tract infection, } \\
\text { inadequate pain management, pressure } \\
\text { ulcers, activity level, use of } \\
\text { antipsychotics, falls, loss of cognition, } \\
\text { catheter, and weight loss }\end{array}$ & $\begin{array}{l}\text { Did not list the } \\
\text { dimensions }\end{array}$ & $\begin{array}{l}\text { Assessments and data } \\
\text { collections performed } \\
\text { by trained nurses }\end{array}$ \\
\hline Malley et al. 2019 & United Kingdom & Cross-sectional & \multicolumn{2}{|c|}{$\begin{array}{l}\text { To investigate the association } 14,172 \text { people aged over } 65 \text { years } \\
\text { between process (experience) living in LTCIs } \\
\text { and quality of life (QoL), } \\
\text { what is most important for } \\
\text { determining QoL, and } \\
\text { whether it is influenced by } \\
\text { the characteristics of the user }\end{array}$} & $\begin{array}{l}\text { Safety, positive experience, and } \\
\text { effectiveness }\end{array}$ & $\begin{array}{l}\text { Safety, positive } \\
\text { experience, and } \\
\text { effectiveness }\end{array}$ & $\begin{array}{l}\text { Quiz, including derived } \\
\text { QoL questions from } \\
\text { the Adult Social Care } \\
\text { Outcomes Toolkit } \\
\text { (ASCOT); } \\
\text { care experience and } \\
\text { user characteristics }\end{array}$ \\
\hline \multicolumn{8}{|c|}{ Structure-process-result model } \\
\hline Fleishman 1998 & Israel & Cross-sectional & $\begin{array}{l}\text { To explain the conceptual } \\
\text { model of regulation, } \\
\text { assessment, and follow-up } \\
\text { (RAF) }\end{array}$ & 220 LTCIs with 13,100 residents & $\begin{array}{l}\text { Care provision system, technical- } \\
\text { professional aspects, client-professional } \\
\text { relationship, and cost }\end{array}$ & $\begin{array}{l}\text { Structure, } \\
\text { work process, and } \\
\text { results }\end{array}$ & $\begin{array}{l}\text { Survey data pertaining } \\
\text { to older adults from } \\
\text { the Aged of the } \\
\text { Ministry of Labor and } \\
\text { Social Affairs }\end{array}$ \\
\hline $\begin{array}{l}\text { Weech-Maldonado, } \\
\text { et al. } 2004\end{array}$ & United States & Cross-sectional & $\begin{array}{l}\text { To relate the structure-- } \\
\text { process-results theory and } \\
\text { direct or indirect workteam } \\
\text { effects on care results }\end{array}$ & 1,135 LTCIs in five US states & $\begin{array}{l}\text { Physical restraint use, antipsychotics, } \\
\text { incidence and worsening of pressure } \\
\text { ulcers, cognitive decline, and mood } \\
\text { decline }\end{array}$ & $\begin{array}{l}\text { Structure, } \\
\text { work process, and } \\
\text { results }\end{array}$ & $\begin{array}{l}\text { Minimum Data Set data } \\
\text { Plus (MDS +), OSCAR } \\
\text { and } \\
\text { structure, } \\
\text { work process, and } \\
\text { results }\end{array}$ \\
\hline
\end{tabular}




\begin{tabular}{|c|c|c|c|c|c|c|c|}
\hline $\begin{array}{l}\text { Laberge } \\
\text { et al. } 2008\end{array}$ & United States & Cross-sectional & $\begin{array}{l}\text { To compare features } \\
\text { of veterans LTCIs } \\
\text { and community LTCIs }\end{array}$ & $\begin{array}{l}192 \text { veteran LTCIs and 24,360 } \\
\text { community LTCIs }\end{array}$ & $\begin{array}{l}\text { Structure - minimum number of trained } \\
\text { nurses, qualified staff, registered nurse } \\
\text { ratio, and hours per resident } \\
\text { Process - prevalence of feeding tube, } \\
\text { mobility restriction, and internal } \\
\text { catheterization } \\
\text { Results - decreased cognitive decline, } \\
\text { and pressure ulcers }\end{array}$ & $\begin{array}{l}\text { Structure, } \\
\text { work process, and } \\
\text { results }\end{array}$ & $\begin{array}{l}\text { OSCAR data from } 1999 \\
\text { to } 2002\end{array}$ \\
\hline $\begin{array}{l}\text { Goodson et al. } 2008 \\
*\end{array}$ & United States & Cross-sectional & $\begin{array}{l}\text { To use a methodology to } \\
\text { aggregate quality indicators } \\
\text { and } \\
\text { to reveal the relationship } \\
\text { between various quality } \\
\text { measures and how they affect } \\
\text { quality in general }\end{array}$ & 234 LTCIs & $\begin{array}{l}\text { Key factors that affect quality: Number } \\
\text { of certified caregivers, bedridden, } \\
\text { physical restraint, the QIC questionnaire; } \\
\text { Number of beds; whether one accepts } \\
\text { Medicare residents; if one is part of a } \\
\text { network of nursing homes; number of } \\
\text { hours of assistants and nurses and } \\
\text { per resident; number of disabilities; } \\
\text { Center for Health Systems Research and } \\
\text { Analysis (CHSRA) at the University of } \\
\text { Wisconsin - Madison - Quality } \\
\text { Indicators }\end{array}$ & $\begin{array}{l}\text { Structure, } \\
\text { work process, and } \\
\text { results }\end{array}$ & $\begin{array}{l}\text { Secondary data with } \\
\text { QIC research results } \\
\text { from the National } \\
\text { Institute of Nursing } \\
\text { Research of the } \\
\text { National Institutes of } \\
\text { Health and primary data } \\
\text { from CHSRA at the } \\
\text { University of Wisconsin } \\
\text { - Madison }\end{array}$ \\
\hline $\begin{array}{l}\text { Kang } \\
\text { et al. } 2011\end{array}$ & United States & Cross-sectional & $\begin{array}{l}\text { To assess the impact } \\
\text { of the geographical location } \\
\text { of rural LTCIs }\end{array}$ & 12,507 residents of 1,174 LTCIs & $\begin{array}{l}\text { Hospital admission in } 90 \text { days after } \\
\text { switching to LTCI, vaccination status, } \\
\text { especially for pneumonia, severe or } \\
\text { moderate pain in the last } 7 \text { days }\end{array}$ & $\begin{array}{l}\text { Structure, } \\
\text { work process, and } \\
\text { results }\end{array}$ & $\begin{array}{l}\text { Data from the } 2004 \\
\text { National Nursing Home } \\
\text { Survey }\end{array}$ \\
\hline $\begin{array}{l}\text { Nasser; Doumit et } \\
\text { al. } 2011\end{array}$ & Lebanon & Qualitative & $\begin{array}{l}\text { To establish a set } \\
\text { of measurable criteria for } \\
\text { LTCIs }\end{array}$ & $\begin{array}{l}\text { Two panel discussions, one with } 19 \\
\text { and } 13 \text { participants }\end{array}$ & $\begin{array}{l}\text { Types of LTCIs, financing, health } \\
\text { services, services offered, activities } \\
\text { (social, spiritual, physical and mental), } \\
\text { structures, and rights of older adults }\end{array}$ & $\begin{array}{l}\text { Structure, } \\
\text { work process, and } \\
\text { results }\end{array}$ & $\begin{array}{l}\text { Discussion panel } \\
\text { between } \\
\text { administrators, } \\
\text { caregivers, and } \\
\text { specialists }\end{array}$ \\
\hline $\begin{array}{l}\text { Thomas } \\
\text { et al. } 2012\end{array}$ & United States & Cross-sectional & $\begin{array}{l}\text { To examine the relationship } \\
\text { between LTCI classifications } \\
\text { on patient safety culture and } \\
\text { care process and results. }\end{array}$ & 3,557 LTCIs & $\begin{array}{l}\text { Structure - patient safety } \\
\text { Process - physical restraint } \\
\text { Results - drop in residents }\end{array}$ & $\begin{array}{l}\text { Structure, } \\
\text { work process, and } \\
\text { results }\end{array}$ & $\begin{array}{l}\text { Questionnaire } \\
\text { distributed to LTCI } \\
\text { directors; } \\
2008 \text { Nursing Home } \\
\text { Survey on PSC (patient }\end{array}$ \\
\hline
\end{tabular}


Kajonius \& Kazemi Switzerland 2016
Cross-sectional

To test empirically

the Donabedian model
95,000 seniors in 324 cities
Structure - income per older person, workers, and training

Process - respect, information, genera satisfaction, and influence on the workteam

safety culture), the

Online Survey,

Certification, and

Reporting Database,

and the Minimum Data Set (MDS)

Swedish data from the

Structure,

work process, and

results

annual national elderly survey (National Board

Health and Welfare 2012).

\section{Consumer-Centered or Person-Centered model}

Lowe et al. $2003 \quad$ United States Cross-sectional

\section{To measure consumer} satisfaction in LTCIs

50 health directors from different

American states

Abbott et al. 2018 United States Cross-sectional
To identify preferences for consumers living in LTCIs
255 older adults in LTCIs and 528

older adults using community-based services
Consumer satisfaction

\section{Preferences.}

Regular contact with family, choosing what to eat, listening to music one likes, regular contact with friends, watching television, having privacy, going outdoors, giving gifts, choosing time of day for bathing, and off-site activities

\section{Consumer satisfaction Questionnaires by} email

Preferences. Analysis of secondary Psychosocial preferences data obtained from and family involvement PELI responses (Preferences for Everyday Living Inventory)

\begin{tabular}{|c|c|c|c|c|c|c|}
\hline \multicolumn{7}{|c|}{ Worker-centered model } \\
\hline Winsløw; Borg, 2008 Denmark & Cross-sectional & $\begin{array}{l}\text { To investigate the } \\
\text { relationship between } \\
\text { workplace resources and } \\
\text { quality of care in } \\
\text { LTCIs }\end{array}$ & $\begin{array}{l}7,500 \text { workers } \\
\text { care from } 36 \text { municipalities }\end{array}$ & $\begin{array}{l}\text { Possibilities to develop at work, } \\
\text { influence, leadership, presence, meaning } \\
\text { at work, commitment, and clarity of the } \\
\text { worker's role }\end{array}$ & Work process & $\begin{array}{l}\text { Standardized } \\
\text { questionnaire }\end{array}$ \\
\hline
\end{tabular}

Source: Authors. 


\subsection{Theoretical models}

We identified 10 studies that used the multidimensional model; eight that used the structure-process-result model (more popularly known as the Donabedian model), two were based on the person-centered model, and one was based on the work environment. One study related the two theories that it employed (multidimensional and structure-process-result). Articles were published between 1990 and 2019.

The articles that used multidimensional models addressed several dimensions of care, including residents and family members, workers and managers, the LTCI`s physical structure, the quality of care, the involvement with the family, and the community. Studies that used the Donabedian model (structure-process-result) assessed the results of the research to verify the quality of care. Meanwhile, studies that adopted the person-centered model considered well-being and quality of life as indicators of good quality. Finally, those that employed the workplace-based approach considered the psychosocial incentive of workers as a key to efficient care at LTCIs.

\subsection{Dimensions of theoretical models for quality assessment and measurement using indicators}

In the structure-process-result model, the dimensions involved several indicators. The structure assessment verified the number of beds (vacancies) at the LTCIs and the qualification of workers $(\mathrm{n}=5)$, as well as the final medical cost per older adult $(n=2)$. The work process emphasized communication $(n=2)$ and an adequate number of workers $(n=2)$. The expected results were defined using indicators referring to the patients' clinical conditions, such as whether they had experienced pressure ulcers, falls, incontinence, infections, cognitive decline, and weight loss.

The dimensions cited in the multidimensional model were care, health status, functional status, well-being, medical services, care planning, work team, family involvement, communication, environment, cost, security, social environment, administrative leadership, culture, positive experience, and effectiveness. The indicators used in these studies were professional performance in providing care $(n=5)$, family involvement $(n=3)$, user satisfaction $(n=2)$, structure $(n=4)$, recreational activities and social interaction $(\mathrm{n}=3)$, and $\operatorname{cost}(\mathrm{n}=1)$.

The person-centered model adopted user satisfaction and family involvement as dimensions. The indicators used in these studies were consumer satisfaction, preferences, regular contact with the family, choice of food, choice of music, regular contact with friends, watching television, having privacy, going outdoors, giving gifts, choosing the time of day to bathe, and activities outside the LTCIs.

The work-centered model only evaluated professional performance. The indicators used were the possibility of development at work, influence, leadership, meaning at work, commitment, and clarity of the worker's role.

Studies by Phillips et al. (1997), Frijters et al. (2013), and Grabowski (2001), despite conceptualizing the quality of care as complex and multidimensional, used indicators based on the structure-process-result model, RAI, interRAI-LTCI, and OSCAR, respectively. Nasser and Doumit et al. (2011) used the Donabedian model, listened to administrators, caregivers, and specialists, but was without the participation of older adults, which is not highly valued by this model.

Some studies have attempted to connect the variables used with actual improvement in quality of care. The variables that had a positive relationship with quality were the workers' psychosocial resources and favorable work environment (Winsløw; Borg 2008), individualized treatment, directing the focus of care to older adults (Abbott et al. 2018), quality of life (Malley et al. 2019), the work process and work teams (Kajonius \& Kazemi 2016), and safety culture (Thomas et al. 2012). 


\section{Discussion}

Measuring the quality of services offered at LTCIs has been a challenge worldwide. The lack of uniformity regarding the concept of quality for LTCIs and the use of multiple dimensions are just some of the difficulties faced. It is important to integrate the perspectives of older adult residents, family members, and professionals when investigating the concept of quality to build tools for assessing the quality of LTCIs (Nakren et al. 2008), because care in LTCIs involves several subjects as residents, workers and managers (Frytak et al. 2001).

In this regard, the multidimensional model assumes that the quality of care needs to involve multiple dimensions. Some studies carried out qualitative research seeking to understand the perceptions of quality from specialists, care providers, care users, and family members to establish these dimensions. The most cited dimensions were the environment, family involvement, human resources, home, individualized care, communication, and a central focus on residents, family, and the community (Gustafson et al. 1990; Rantz et al. 1999; Thompson et al. 2012). From this, the QAI (Gustafson et al. 1990) and OIQ were constructed for researchers, users, and regulators interested in observing and evaluating the quality of care in LTCIs, based on a multidimensional theoretical model (Rantz et al, 2000; 2002). The studies that used this model were more comprehensive, with multiple dimensions, with regard to the evaluation of care.

The use of the structure-process-result model was justified by the authors that employed the model by the need for an evaluation that would guarantee the delivery of good quality service to residents. It connects structure, process, and results as the key to achieving good quality, and each of these dimensions has several indicators. The structure involves material, human, and organizational resources; the process involves activities related to care itself; the results refer to the effect of care on the patient's condition (Fleishman 1988). The most common criticism regarding the use of the Donabedian model is that it is adapted from the industry that aims to produce objects and not services, without having as a central point the health and wellbeing of people (Unruh \& Wan, 2004; Harrington et al. 2005), and that there is not enough detail to truly meet the needs of users or to develop a care plan (Degenholtz et al. 2014). In general, studies that support this model use fewer comprehensive variables than multidimensional models. None of the included studies evaluated family involvement or recreational activities. Many studies using secondary data and normally available tools are based on this theory, such as the Minimum Data Set (MDS) (Weech-Maldonado et al. 2004; Thomas et al. 2012) and OSCAR (Grabowski, 2001; Weech-Maldonado, et al. 2004; Laberge et al. 2008). Some authors, even without supporting this theory, used the same data. Generally, these tools are used to define financing and to compare the LTCI's quality services (Fleishman 1998; Laberge et al. 2008; Kang et al. 2011; Thomas et al. 2012; Weech-Maldonado et al. 2004).

In the person-centered model, the first study found that the quality of care is based on the person and his well-being, and quality of life is a frequently used indicator (Lowe et al. 2003). The second address the patient's holistic view, and his physical, mental and psychosocial health is considered to meet the individuality and desire of the person (Abbott et al. 2018). This model values individual preferences and is against the traditional biomedical care management model, in which the health professional defines the treatment without the patient's participation. Five principles govern this theoretical model: empowerment, respect, patient involvement, access, and support for appropriate treatment (International Alliance of Patients' Organizations, 2007). In general, there are criticisms from a person-centered organization because it is believed that it is not strongly oriented toward equity in health, since it is believed that to create equitable health systems, it is essential to analyze the perception of users and those involved, as well as the workers who have the potential to identify disparities in health care and who can contribute to increasing the quality of care (Cunningham et al. 2014; David et al., 2020).

The theoretical model that related the work environment was found only in one study (i.e., Winsløw and Borg 2008), being defined as the frequency at which workers perform actions for users, which promotes well-being and quality of life. This 
raises the hypothesis that a sufficient number of workers with adequate qualification in an environment that favors the psychosocial aspects of these workers leads to the provision of a better quality of care (Lindolpho et al., 2020; Machado et al., 2020). A relationship was identified between psychosocial aspects (influence, possibilities of development, meaning of work, commitment, clarity of functions, predictability, and leadership) and quality of care (Winsløw; Borg 2008). Studies have shown that professional satisfaction is mediated by proactive behaviors (Khatri et al. 2016; Tourangeou et al. 2017; Backhaus et al. 2017) and that career and job satisfaction is related to the quality of service provided to the consumer (Spence et al. 2016). However, there was no evidence of an association between quality and payment for performance (Glickman et al. 2007).

The focus on just a few indicators may not substantially improve quality; several indicators are required for this to occur (Goodson et al. 2008; Thompson et al. 2012; Kontezka, 2019, Song et al. 2019; Minayo 2019).

With regard to theoretical models, most are incomplete or have not been created specifically to assess LTCIs. Difficult factors in the assessment are those intrinsic to older adults, such as age and genetic load, which cannot be controlled and affect clinical indicators (Unruh \& Wan., 2004; Harrington et al. 2005). Another factor is related to the indicators themselves; generally, little has changed over time, not been validated, and not necessarily related to improvement in the quality of care (Young 2014; Medeiros et al. 2016; Kottner et al. 2018; Burke \& Werner 2019; Armijo-Olivo et al. 2020).

For a good evaluation, it is necessary to search for concepts with a broad understanding (Bond et al. 2018) and choose the elements that will constitute the evaluation, assuming that the lowest quality is associated with inefficiency (Donabedian 1988). The evaluation, in general, should vary according to time, internal culture and also include qualitative aspects, although difficult to numerically measure (Adom et al. 2018, Collins et al. 2018, Varpio et al. 2019).

This review provides a comprehensive, relevant, and up-to-date view of the theoretical models used to assess LTCIs. A strong point of this study is that the quality models used to evaluate LTCIs drive advances in evaluation models with positive results. Additionally, multi-base and peer searching strengthen research. There is still a long way to go to improve the quality of care assessment processes in LTCIs, which attends a population that is growing rapidly in the world.

A multidimensional model with comprehensive dimensions including all those involved (consumers, residents, and family members, managers, and workers), with an outstanding assessment of worker and resident satisfaction, would be the best way to better capture the current moment of quality of care and what will be necessary to improve it.

\section{Conclusion}

Four theoretical models were used to assess the quality of care in LTCIs: multidimensional, structure-process-result, person-centered, and centered on the work-centered.

There are dimensions and some common indicators between models. The indicators of the model work and personcentered are also part of the multidimensional and Donabedian models.

The theoretical model influences the construction of evaluation systems. The more comprehensive the assessment, the more likely the quality will be achieved.

Multidimensionality must be considered when assessing the quality of care in LTCIs, which must be performed continuously.

More studies must be developed to evaluate the quality of care offered in LTCI based on quality theoretical frameworks, considering the several dimensions of the quality concept. In the same sense, there is a need to develop valid and reliable indicators to measure these quality aspects. In this way, the evaluative studies will improve the quality of care, health, and well-being of institutionalized older adults. 


\section{Declarations}

Funding - This study is part of PhD thesis developed in Universidade Federal de Minas Gerais (School of Dentistry). This study was financed in part by the Coordenação de Aperfeiçoamento de Pessoal de Nível Superior - Brasil (CAPES) Finance Code 001. Raquel Conceição Ferreira received financial support from FAPEMIG, Brazil (Fundação de Amparo à Pesquisa do Estado de Minas Gerais - Programa Pesquisador Mineiro - PPM-00603-18)

\section{References}

Abbott, K. M., Klumpp, R., Leser, K. A., Straker, J. K., Gannod, G. C., \& Van Haitsma, K. (2018). Delivering person-centered care: important preferences for recipients of long-term services and supports. Journal of the American Medical Directors Association, 19(2), 169-173.

Adom, D., Hussein, E. K., \& Agyem, J. A. (2018). Theoretical and conceptual framework: Mandatory ingredients of a quality research. International journal of scientific research, 7(1), 438-441.

Armijo-Olivo, S., Craig, R., Corabian, P., Guo, B., Souri, S., \& Tjosvold, L. (2020). Nursing staff time and care quality in long-term care facilities: a systematic review. The Gerontologist, 60(3), e200-e217.

Armstrong, R., Hall, B. J., Doyle, J., \& Waters, E. (2011). 'Scoping the scope'of a cochrane review. Journal of public health, 33(1), 147-150.

Burke R.E., \& Werner R.M. (2019) Quality measurement and nursing homes: measuring what matters. BMJ qual Saf. 28:520-523.

Collins, C. S., \& Stockton, C. M. (2018). The central role of theory in qualitative research. International Journal of Qualitative Methods, 17(1), 1609406918797475.

Cunningham, B. A., Marsteller, J. A., Romano, M. J., Carson, K. A., Noronha, G. J., McGuire, M. J., \& Cooper, L. A. (2014). Perceptions of health system orientation: quality, patient centeredness, and cultural competency. Medical Care Research and Review, 71(6), 559-579.

David, C. S. de, Cerezer, J. P., Moura, L. V., Flores, M. T. F. D., Machado, V. K., Rodrigues, R. F. de L., \& Carlesso, J. P. P. (2020). The self-esteem of elderly women in a support association: experience report. Research, Society and Development, 9(3), e57932364.

Degenholtz, H. B., Resnick, A. L., Bulger, N., \& Chia, L. (2014). Improving quality of life in nursing homes: the structured resident interview approach. Journal of aging research, 2014.

Medeiros, P. A. D., Fortunato, A. R., Viscardi, A. A. D. F., Sperandio, F. F., \& Mazo, G. Z. (2016). Instruments developed for the management and care of the elderly in long-stay care institutions: a systematic review. Ciencia \& saude coletiva, 21(11), 3597-3610.

Donabedian, A. (1992). The role of outcomes in quality assessment and assurance. QRB-Quality Review Bulletin, 18(11), 356-360.

Dyer, S., Valeri, M., Arora, N., Ross, T., \& Winsall, M. (2019). Review of international systems of long-term care of older people. https://agedcare.royalcommission.gov.au/sites/default/files/2020-01/research-paper-2-review-international-systems-long-term-care.pdf

Fleishman, R. (1998). An innovative method of government surveillance of services for the aged in Israel. International Journal of Health Care Quality Assurance. 11(4-5), 161-72.

Frijters, D. H., van der Roest, H. G., Carpenter, I. G., Finne-Soveri, H., Henrard, J. C., Chetrit, A., ... \& Bernabei, R. (2013). The calculation of quality indicators for long term care facilities in 8 countries (SHELTER project). BMC health services research, 13(1), 1-10.

Frytak, J. R., Kane, R. A., Finch, M. D., Kane, R. L., \& Maude-Griffin, R. (2001). Outcome trajectories for assisted living and nursing facility residents in Oregon. Health Services Research, 36(1 Pt 1), 91.

Gilissen, J., Pivodic, L., Smets, T., Gastmans, C., Vander Stichele, R., Deliens, L., \& Van den Block, L. (2017). Preconditions for successful advance care planning in nursing homes: a systematic review. International journal of nursing studies, 66, 47-59.

Glickman, S. W., Ou, F. S., DeLong, E. R., Roe, M. T., Lytle, B. L., Mulgund, J., \& Peterson, E. D. (2007). Pay for performance, quality of care, and outcomes in acute myocardial infarction. Jama, 297(21), 2373-2380.

Goodson, J., Jang, W., \& Rantz, M. (2008). Nursing home care quality: Insights from a Bayesian network approach. The Gerontologist, 48(3), $338-348$.

Grabowski, D. C. (2001). Does an increase in the Medicaid reimbursement rate improve nursing home quality? The Journals of Gerontology: Social Sciences, $56 \mathrm{~B}(2), \mathrm{S} 84-\mathrm{S} 93$.

Gustafson, D. H., Sainfort, F. C., Van Konigsveld, R., \& Zimmerman, D. R. (1990). The Quality Assessment Index (QAI) for measuring nursing home quality. Health Services Research, 25(1 Pt 1), 97.

Harrington, C. (2005). Quality of care in nursing home organizations: Establishing a health services research agenda. Nursing Outlook, 53(6), 300-304.

International Alliance of Patients' Organizations (2007) What is Patient-Centered Health Care? A Review of Definitions and Principles. London https://iapo.org.uk/sites/default/files/files/IAPO\%20Patient-Centred\%20Healthcare\%20Review\%202nd\%20edition.pdf 
Joshua, L. (2017). Aging and long-term care systems: a review of finance and governance arrangements in Europe, North America and Asia-Pacific. World Bank, Washington.

Kajonius, P. J., \& Kazemi, A. (2016). Structure and process quality as predictors of satisfaction with elderly care. Health \& social care in the community, 24(6), 699-707.

Kang, Y., Meng, H., \& Miller, N. A. (2011). Rurality and nursing home quality: Evidence from the 2004 National Nursing Home Survey. The Gerontologist, 51(6), 761-773.

Khatri, N., Gupta, V., \& Varma, A. (2017). The relationship between HR capabilities and quality of patient care: The mediating role of proactive work behaviors. Human resource management, 56(4), 673-691.

Konetzka, R. T. (2020). The challenges of improving nursing home quality. JAMA network open, 3(1), e1920231-e1920231.

Kottner, J., Hahnel, E., Lichterfeld-Kottner, A., Blume-Peytavi, U., \& Büscher, A. (2018). Measuring the quality of pressure ulcer prevention: a systematic mapping review of quality indicators. International wound journal, 15(2), 218-224.

Laberge, A., Weech-Maldonado, R., Johnson, C. E., Jia, H., \& Dewald, L. (2008). Outsourcing veterans for long term care: comparison of community and state veterans'nursing homes. Journal of health and human services administration, 30 (4), 441-467.

Knoester, M., \& Plikuhn, M. (2016). Influence of siblings on out-of-school reading practices. Journal of Research in Reading, 39(4), 469-485.

Lowe, T. J., Lucas, J. A., Castle, N. G., Robinson, J. P., \& Crystal, S. (2003). Consumer satisfaction in long-term care: State initiatives in nursing homes and assisted living facilities. The Gerontologist, 43(6), 883-896.

Lindolpho, M. da C., Sá, S. P. C. Valente, G. S. C., Reis, L. B. do, Silva, M. H. A. da ., \& Barros, N. K. R. O. . de (2020). Self-care and quality of life in elderly caregivers. Research, Society and Development, 9(9), e183996731

Machado, E. A. Santo, F. H. do E. ., Ribeiro, M. de N. de S. ., Silvino, Z. R. ., Cardoso, R. da S. S. ., Almeida, E. G. R. ., \& Aranha, J. dos S. . (2020). Aging and fall prevention: overview of the nursing team of a Transition Hospital. Research, Society and Development, 9(10), e2749108566.

Malley, J., D'Amico, F., \& Fernandez, J. L. (2019). What is the relationship between the quality of care experience and quality of life outcomes? Some evidence from long-term home care in England. Social Science \& Medicine, 243, 112635.

Milte, R., Ratcliffe, J., Bradley, C., Shulver, W., \& Crotty, M. (2019). Evaluating the quality of care received in long-term care facilities from a consumer perspective: development and construct validity of the Consumer Choice Index-Six Dimension instrument. Ageing \& Society, 39(1), 138-160.

Minayo, M. C. D. S. (2019). O imperativo de cuidar da pessoa idosa dependente. Ciência \& Saúde Coletiva, 24, 247-252.

Katzman, J. L., Shaham, U., Cloninger, A., Bates, J., Jiang, T., \& Kluger, Y. (2018). DeepSurv: personalized treatment recommender system using a Cox proportional hazards deep neural network. BMC medical research methodology, 18(1), 1-12.

Nakrem, S., Vinsnes, A. G., Harkless, G. E., Paulsen, B., \& Seim, A. (2009). Nursing sensitive quality indicators for nursing home care: international review of literature, policy and practice. International Journal of Nursing Studies, 46(6), 848-857.

Nasser, R., \& Doumit, J. (2011). Developing criteria for elderly nursing homes: the case of Lebanon. International journal of health care quality assurance.24 (3), 211-222

Onder, G., Carpenter, I., Finne-Soveri, H., Gindin, J., Frijters, D., Henrard, J. C., ... \& Bernabei, R. (2012). Assessment of nursing home residents in Europe: the Services and Health for Elderly in Long TERm care (SHELTER) study. BMC health services research, 12(1), 1-10.

Peters, M., Godfrey, C., McInerney, P., Soares, C. B., Khalil, H., \& Parker, D. (2015). Methodology for JBI scoping reviews. In The Joanna Briggs Institute Reviewers Manual 2015 (pp. 3-24). Joanna Briggs Institute.

Phillips, C. D., Zimmerman, D., Bernabei, R., \& Jonsson, P. V. (1997). Using the Resident Assessment Instrument for quality enhancement in nursing homes Age and Ageing, 26(suppl_2), 77-81.

Rantz, M., Jensdottir, A. B., Hjaltadottir, I., Gudmundsdottir, H., Sigurveig Gudjonsdottir, J., Brunton, B., \& Rook, M. (2002). International field test results of the observable indicators of nursing home care quality instrument. International Nursing Review, 49(4), 234-242.

Rantz, M. J., Mehr, D. R., Petroski, G. F., Madsen, R. W., Popejoy, L. L., Hicks, L. L., ... \& Maas, M. (2000). Initial field testing of an instrument to measure: observable indicators of nursing home care quality. Journal of Nursing Care Quality, 14(3), 1-12.

Rantz, M. J., Zwygart-Stauffacher, M., Popejoy, L., Grando, V. T., Mehr, D. R., Hicks, L. L., .. \& Maas, M. (1999). Nursing home care quality: A multidimensional theoretical model integrating the views of consumers and providers. Journal of nursing care quality, 14(1), 16-37.

Sainfort, F., Ramsay, J. D., \& Monato Jr, H. (1995). Conceptual and methodological sources of variation in the measurement of nursing facility quality: An evaluation of 24 models and an empirical study. Medical Care Research and Review, 52(1), 60-87.

Sanford, A. M., Orrell, M., Tolson, D., Abbatecola, A. M., Arai, H., Bauer, J. M., ... \& Vellas, B. (2015). An international definition for "nursing home". Journal of the American Medical Directors Association, 16(3), 181-184.

Scheffelaar, A., Bos, N., Hendriks, M., Van Dulmen, S., \& Luijkx, K. (2018). Determinants of the quality of care relationships in long-term care-a systematic review. BMC health services research, 18(1), 1-23. 
Research, Society and Development, v. 10, n. 8, e17110817117, 2021

(CC BY 4.0) | ISSN 2525-3409 | DOI: http://dx.doi.org/10.33448/rsd-v10i8.17117

Sion, K. Y., Verbeek, H., de Boer, B., Zwakhalen, S. M., Odekerken-Schröder, G., Schols, J. M., \& Hamers, J. P. (2020). How to assess experienced quality of care in nursing homes from the client's perspective: Results of a qualitative study. BMC geriatrics, 20(1), 1-12.

Song, Y., Hoben, M., Norton, P., \& Estabrooks, C. A. (2020). Association of work environment with missed and rushed care tasks among care aides in nursing homes. JAMA network open, 3(1), e1920092-e1920092.

Spasova, S., Baeten, R., \& Vanhercke, B. (2018). Challenges in long-term care in Europe. Eurohealth, 24(4), 7-12.

Spence Laschinger, H. K., Zhu, J., \& Read, E. (2016). New nurses' perceptions of professional practice behaviors, quality of care, job satisfaction and career retention. Journal of Nursing Management, 24(5), 656-665.

Thomas, K. S., Hyer, K., Castle, N. G., Branch, L. G., Andel, R., \& Weech-Maldonado, R. (2012). Patient safety culture and the association with safe resident care in nursing homes. The Gerontologist, 52(6), 802-811.

Thompson, S. A., Bott, M., Gajewski, B., \& Tilden, V. P. (2012). Quality of care and quality of dying in nursing homes: two measurement models. Journal of palliative medicine, 15(6), 690-695.

Tourangeau, A. E., Patterson, E., Saari, M., Thomson, H., \& Cranley, L. (2017). Work-related factors influencing home care nurse intent to remain employed. Health Care Management Review, 42(1), 87-97.

Tricco, A. C., Lillie, E., Zarin, W., O’Brien, K., Colquhoun, H., Kastner, M., ... \& Straus, S. E. (2016). A scoping review on the conduct and reporting of scoping reviews. BMC medical research methodology, 16(1), 1-10.

Trinkoff, A. M., Yoon, J. M., Storr, C. L., Lerner, N. B., Yang, B. K., \& Han, K. (2020). Comparing residential long-term care regulations between nursing homes and assisted living facilities. Nursing outlook, 68(1), 114-122.

Unruh, L., \& Wan, T. T. (2004). A systems framework for evaluating nursing care quality in nursing homes. Journal of medical systems, 28(2), 197-214.

Varpio, L., Paradis, E., Uijtdehaage, S., \& Young, M. (2020). The distinctions between theory, theoretical framework, and conceptual framework. Academic Medicine, 95(7), 989-994.

Wagner, A., Schaffert, R., Möckli, N., Zúñiga, F., \& Dratva, J. (2020). Home care quality indicators based on the Resident Assessment Instrument-Home Care (RAI-HC): a systematic review. BMC health services research, 20, 1-12.

Weech-Maldonado, R., Meret-Hanke, L., Neff, M. C., \& Mor, V. (2004). Nurse staffing patterns and quality of care in nursing homes. Health Care Management Review, 29(2), 107-116.

Winsløw, J. H., \& Borg, V. (2008). Resources and quality of care in services for the elderly. Scandinavian Journal of public health, 36(3), $272-278$.

World Health Organization. (2006). The world health report 2006: working together for health. World Health Organization.

World Health Organization. (2017) Towards long-term care systems in sub-Saharan Africa. WHO series on long-term care. Geneva: World Health Organization.

Young, M. (2014). Curriculum theory: what it is and why it is important. Cadernos de Pesquisa, 44(151), 190-202. 